\title{
Basin of upper Paraíba river course - PB, Brazil and its rainfall analysis
}

\author{
Bacia hidrográfica do alto curso do rio Paraíba - PB, Brasil e sua análise pluviométrica \\ Cuenca hidrográfica del curso alto del río Paraíba - PB, Brasil y su análisis pluviométrico
}

Received: 05/06/2021 | Reviewed: 05/13/2021 | Accept: 05/31/2021 | Published: 06/14/2021

\author{
Raimundo Mainar de Medeiros \\ ORCID: https://orcid.org/0000-0003-3455-9876 \\ Universidade Federal de Campina Grande, Brazil \\ E-mail: mainarmedeiros@gmail.com \\ Moacyr Cunha Filho \\ ORCID: https://orcid.org/0000-0002-3466-8143 \\ Universidade Federal Rural de Pernambuco, Brazil \\ E-mail: moacyr.cunhafo@ufrpe.br \\ Victor Casimiro Piscoya \\ ORCID: https://orcid.org/0000-0003-1875-9771 \\ Universidade Federal Rural de Pernambuco, Brazil \\ E-mail: victor.piscoya@ufrpe.br \\ Renisson Neponuceno de Araújo Filho \\ ORCID: https://orcid.org/0000-0002-9747-1276 \\ Universidade Federal do Tocantins, Brazil \\ E-mail: renisson@uft,edu.br \\ Manoel Vieira de França \\ ORCID: https://orcid.org/0000-0003-4973-9327 \\ Universidade Federal Rural de Pernambuco, Brazil \\ E-mail: manoelvieiraufrpe@gmail.com \\ Nayane Laísa de Lima Cavalcanti \\ ORCID: https://orcid.org/0000-0003-4585-992X \\ Universidade Federal Rural de Pernambuco, Brazil \\ E-mail: nayane.l.cavalcanti@gmail.com \\ Thaísa Oliveira Folha Piscoya \\ ORCID: https://orcid.org/0000-0002-8419-1566 \\ Superintendência do Desenvolvimento do Nordeste, Brazil \\ E-mail: thaisafolha@gmail.com \\ Jorge Luís Piscoya Roncal \\ ORCID: https://orcid.org/0000-0001-8474-6771 \\ Universidad Nacional de Trujillo, Peru \\ E-mail: jpiscoya@unitru.edu.pe \\ Sóstenes Gomes de Sousa \\ ORCID: https://orcid.org/0000-0002-7719-2907 \\ Universidade Federal Rural de Pernambuco, Brazil \\ E-mail: sostenesgomees@gmail.com \\ Alex Souza Moraes \\ ORCID: https://orcid.org/0000-0002-4324-8271 \\ Universidade Federal Rural de Pernambuco, Brazil \\ E-mail: alex.moraes@ufrpe.br \\ Luciano Marcelo Falle Saboya \\ ORCID: https://orcid.org/0000-0002-7586-6867 \\ Universidade Federal de Campina Grande, Brazil \\ E-mail: 1saboya@hotmail.com
}

\begin{abstract}
Precipitation is of extreme importance for the management of water resources, since it is a question of degraded areas and with deforestation for deforestation and the withdrawal of firewood. Frequency analysis was performed on the annual rainfall totals by drawing up the graphs. The scale proposed by Meis et al. (1981), and by the meteorological and CPTEC/INPE nuclei, and provided by Xavier et al. (2005), the annual values that approached the mean value were characterized as intermediaries, and in the scale of annual precipitation values, those that moved away $25 \%$ away from the average were considered as very rainy years, and below $25 \%$, like dry years. The application of the Student's t test of significance, pointed out that precipitation data in general are $99 \%$ significant. The results showed a tendency of reductions in the rainfall indices, with oscillations of precipitations throughout the series 1962 to 2019, and evidenced the recurrence of maximum values of annual precipitation in the range of 17, 13 and 9 years. It is suggested a study with
\end{abstract}


series of larger years in order to verify the fluctuations and the contributions of the El Niño(a) phenomena in the studied area.

Keywords: Sustainability; Climatic characterization; Climate variability.

\section{Resumo}

A precipitação é de extrema importância para o gerenciamento dos recursos hídricos, uma vez que se trata de áreas degradadas e com realização de desmatamento para implantações de agricultura de sequeiro e a retirada da lenha. Efetuou-se análise de frequência nos totais anuais das chuvas mediante a elaboração dos gráficos. Utilizou-se a escala proposta por Meis et al. (1981) e pelos núcleos de meteorologia e CPTEC/INPE e, disponibilizada por Xavier et al. (2005), os valores anuais que se aproximaram do valor médio foram caracterizados como intermediários, e na escala de valores de precipitação anual, aqueles que se afastaram $25 \%$ em relação à média foram considerados como anos muito chuvosos, e abaixo dos 25\%, como anos secos. A aplicação do teste de significância T de Student destacou que os dados de precipitação de modo geral são $99 \%$ significativos. Os resultados mostraram tendência de reduções dos índices pluviométricos, com oscilações das precipitações ao longo da série 1962 a 2019 e evidenciou-se a recorrência de valores máximos de precipitação anual no intervalo de 17, 13 e 9 anos. Sugere-se estudo com série de maiores anos a fim de verificar as flutuações e as contribuições dos fenômenos El Niño (a) na área estudada.

Palavras-chave: Sustentabilidade; Caracterização climática; Variabilidade climática.

\section{Resumen}

La precipitación es de suma importancia para el manejo de los recursos hídricos, ya que se trata de áreas degradadas con deforestación para la agricultura de secano y extracción de leña. El análisis de frecuencia se realizó sobre los totales anuales de lluvia mediante la elaboración de los gráficos. La escala propuesta por Meis et al. (1981) y por los núcleos de meteorología y CPTEC / INPE, y puestos a disposición por Xavier et al. (2005), los valores anuales que se acercaron al valor promedio se caracterizaron como intermedios, y en la escala de valores de precipitación anual, aquellos que se alejaron un $25 \%$ del promedio se consideraron años muy lluviosos, y por debajo del $25 \%$, como años secos. La aplicación de la prueba de significancia $\mathrm{T}$ de Student destacó que los datos de precipitación en general son 99\% significativos. Los resultados mostraron una tendencia a la disminución de las precipitaciones, con fluctuaciones en las precipitaciones durante la serie de 1962 a 2019, y hubo una recurrencia de los valores máximos de precipitación anual en el rango de 17, 13 y 9 años. Se sugiere un estudio con una serie de años anteriores para verificar las fluctuaciones y contribuciones de los fenómenos de El Niño (a) en el área estudiada.

Palabras clave: Sostenibilidad; Caracterización climática; Variabilidad climática.

\section{Introduction}

Precipitation is considered a relevant factor in the provision of various socioeconomic and environmental activities, in which hydroelectric plants, industries, agriculture and cattle raising and the increase of reservoir levels for human supply purposes stand out. For Kulkarni et al. (2013), rains are highly important, especially in tropical regions and are considered the main point of convective processes that occur in the atmosphere.

It is important to analyze trends in historical rainfall series to verify inter-annual and ten-year climate variability, thus being able to identify how climate changes can modulate these temporal patterns of variability.

Investigations about variability and climate change consider variations in rainfall as an index for detecting climate change because it has a reasonably long observational record and is easy to estimate. The analysis of rainfall behavior in the Northeast of Brazil (NEB) has great relevance, mainly due to its irregularity, since climate variables are very important not only from the climate perspective, but also the consequences of social and economic order. According to Zanella (2006), in these last decades, several phenomena linked to the new climatic conditions in cities, such as the increase in temperature, atmospheric pollution, more intense rains, among others, become part of the daily life of the population, becoming vulnerable to numerous problems resulting therefrom.

Medeiros et al. (2015) carried out an analysis of the climate and the availability of surface and underground water resources in the municipality of São João do Cariri, state of Paraíba. They found that in terms of climate, water resources and the real water needs for the main activities of importance economic, visualized through the water balance, the municipality needs rainwater storage, since the groundwater is not enough and also does not present satisfactory quality for domestic use and for other purposes. 
Different authors have evaluated the trend in precipitation observed in NEB during the 20th century. For example, Haylock et al. (2006) carried out an analysis of precipitation over South America and observed an upward trend in the total annual rainfall over NEB. The study by Santos et al. (2007), using indexes of climatic extremes and correlating them with sea surface temperature anomalies (TSM), also showed a tendency towards an increase in total annual precipitation in the states of Paraíba and Rio Grande do Norte. Still, Santos et al. (2007) showed trends of increased precipitation for the state of Ceará.

According to Marengo (2012), the NEB region is naturally characterized by a high water evaporation potential due to the great availability of solar energy and high temperatures. Temperature increases associated with climate change resulting from global warming, regardless of what may happen with the rains, and would be enough to cause greater evaporation of lakes, dams and reservoirs and greater evaporative demand from plants. That is, unless there is an increase in rainfall, water will become a much scarcer commodity, with serious consequences for the sustainability of regional development.

With the objective of analyzing climate changes on the NEB and aiming at the importance of conceptualizing the processes that influence the pattern of pluviometric distributions, both spatial and temporal, it was observed that the relevant factor to be highlighted is the irregularity of the distributions of the rainfall indexes, associated with the high interannual variability of precipitation in the tropical region, with dry and rainy years. Different factors contribute to explain the variability of precipitation over the NEB, among which can be mentioned the fluctuation in the TSM's values of the South Tropical Pacific Ocean and the South Atlantic. In general, the values of the TSM's anomalies, the Tropical Pacific and the Atlantic they are associated with changes in the general circulation pattern of the atmosphere and consequent variations in NEB precipitation according to Araújo (2009).

On the other hand, nowadays, the importance of research involving the study of the climate in the search for the construction of new knowledge parameters and consequent application in the various human activities (agriculture, water damming, agriculture, economy, commerce, leisure, irrigation, hydrology and other sciences) is noticeable. These activities depend on increasingly concise data and information on rainfall, temporal droughts and extreme events, in short, medium and long-term information generated with a high degree of accuracy (Vieira, 2010).

Precipitation is a climatic element with greater temporal space variability. For this reason, the study of extreme events of maximum daily annual precipitation is related to severe damage to human activities in all regions of the world, due to its potential to cause water saturation of the soil, runoff and erosion in accordance with the Intergovernmental Panel on Climate Change (IPCC) (2007) and Tammets et al. (2013).

Monitoring the region's rainfall regime in recent years has shown that the scarcity of water resources accentuates socioeconomic problems, particularly at the end of each year, with rainfall totals around or below the region's average according to Marengo et al. (2006).

Water planning is the basis for dimensioning any form of integrated management of water resources. Thus, the water balance allows the knowledge of the need and availability of water in the soil over time. The water balance, as a management unit, allows to classify the climate of a region, to carry out the agroclimatic and environmental zoning, the period of availability and water need in the soil, in addition to favoring the integrated management of water resources (Lima, 2009).

The climate exerts a great influence on the operating environment as a factor of interactions between (a)biotic components. The climate located in the different latitudes of the globe does not present the same characteristics in each year according to Soriano (1997). In regions with contrasting climates (rainy and semi-arid sides), such as the NEB and especially the state of Paraíba, monitoring the precipitation, especially during the rainy season, is important for making decisions that bring benefits to the population. According to Santana et al. (2007), due to this, the seasonality of precipitation concentrates almost all of its volume during the five to six months in the rainy season, according to Silva (2004).

The climatic variability of a given region has an important influence on the various socioeconomic, agricultural and 
hydrological activities. Since the climate consists of a set of integrated elements, determinant for human survival, which acquires relevance, since its configuration can facilitate or hinder the fixation of man and the development of his activities in the different regions of the planet. Among the climatic elements, precipitation plays a major role in the development of human activities, producing results in the economy according to Sleiman (2008).

Sant'anna Neto (2008) studied that the climate and its impacts, in a geographical perspective, must reach two levels: that of the socioeconomic dimension and that of the environmental dimension. In the socioeconomic dimension, it understands the influence of atmospheric phenomena and climatic patterns in the structuring of the territory and in the daily life of society, a territory that can be modified due to the variability resulting from climate changes.

According to Tucci (2002), the definitions used in the literature about climate change differ according to the inclusion of anthropic effects in the identification of variability. The IPCC (2007) defines climate change as temporal changes in climate due to natural variability and/or results of human activities. Other authors, such as Eerola (2003), Ichikawa (2004) and Sturm et al. (2005), for the same term, adopt the definition of changes associated (in)directly with human activities that alter the natural climatic variability observed in a period.

According to Meis et al. (1981), precipitations over time can be analyzed in different ways, enabling the recognition of their general behavior, their habitual and extreme patterns.

The distribution of precipitation in northeastern Brazil is quite uneven in time and space, in addition, the rainy season occurs differently, in quantity, duration and distribution. The objective for the hydrographic basin of the upper course of the Parnaíba River - PB, Brazil is to analyze the rainfall variation in the period from 1962 to 2019. This study is relevant, since the studied area is characterized by having a variability in rainfall indexes and a diversity in soil occupation patterns, where the impacts of rainfall have a great influence on the studied area, extreme events affect the socioeconomic, agricultural and livestock issues and the damming of water.

\section{Methodology}

The Paraíba River Upper Course Basin (BHACRP), with an area of 20,071.83 km2, between latitudes 6 $6^{\circ} 51^{\prime} 31^{\prime \prime}$ and

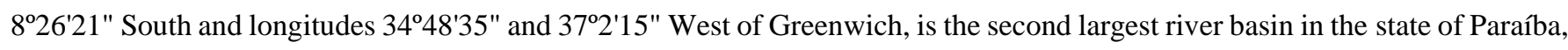
it covers $38 \%$ of its territory with 1,828,178 inhabitants corresponding to $52 \%$ of its total population. Considered one of the most important basins in the northeastern semi-arid region, it comprises the sub-basin of the Taperoá River and the Upper Course of the Paraíba River, the Middle Course of the Paraíba River and the Low Course of the Paraíba River. In addition to the high population density, the basin includes the cities of João Pessoa, capital of Paraíba, and Campina Grande, its second largest urban center (Figure 1). 
Figure 1. Location of the Upper Course of the Paraíba River basin.
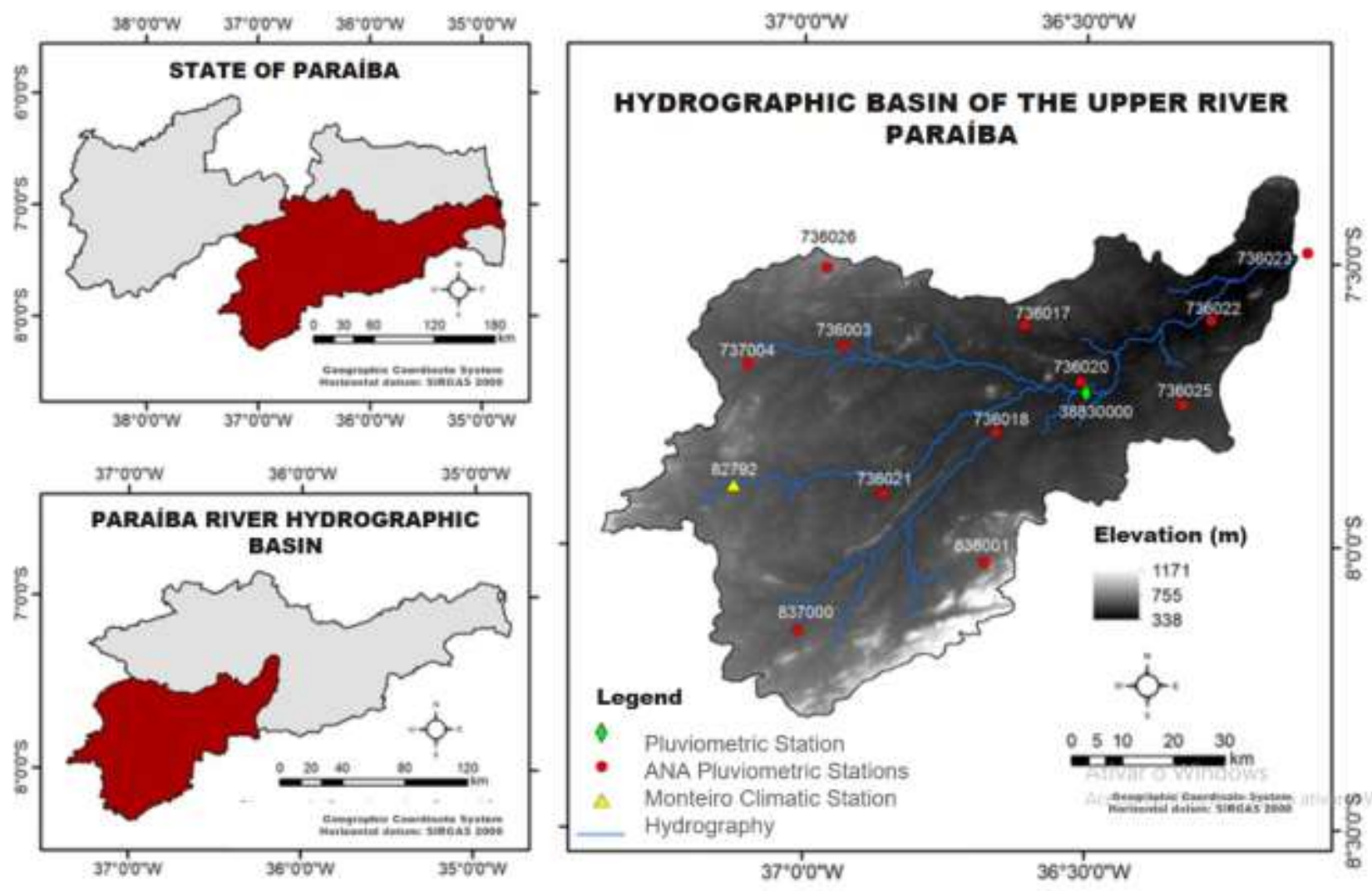

Source: Silva et al. (2016).

The basin is formed by regions afflicted by local, regional and large-scale synoptic events causing rain, such as the Intertropical Convergence Zone (ITCZ) and, when active on the NEB, the contributions of the High Level Cyclonic Vortex systems (HLCVs). In addition, there are the effects of the northeast trade winds together with the effects of sea breeze, aided by the formation of the South Atlantic Cyclonic Vortexes (SACVs), the instability lines (IL), the Dipole Pattern (DP) in the Tropical Atlantic Ocean and wave disturbances in the field of trade winds, providing events for droughts, floods, inundations, overflow of rivers, dams, muds, ponds, lakes and streams. Most of the river runoff at the headwaters is temporary due to poor rainfall distribution. In the region of Paraiba, the increase in its rainfall levels in the rainy season causes a significant increase in runoff, in which the majority is dammed in large and medium dams and its excess, after the damming, flows slowly into the ocean due to the relief and its basic water courses in accordance with Medeiros (2016).

The relief presents itself in a very diversified way, constituting different forms of relief worked and by different processes, acting under different climates and on little or very differentiated rocks. Regarding geomorphology, there are three groups formed by the most significant climatic types: humid, sub-humid and semi-arid. Current use and vegetation cover are characterized by forest formations defined as open tree shrub caatinga, closed tree tree shrub caatinga, closed tree caatinga, coastal board, mangroves, humid forest, semi-deciduous forest, Atlantic Forest and sandbank.

It used series of monthly and annual precipitation data collected by the Northeast Development Superintendence (SUDENE) (1990) and provided by the Executive Water Management Agency of the State of Paraíba (AESA) (2019), for the twelve municipalities that bypass Paraíba River Upper Course Watershed (BHACRP) represented in Table 1. 
Table 1. Location of the municipalities and their geographic coordinates, with the period of monthly and annual rainfall observations.

\begin{tabular}{|c|c|c|c|c|}
\hline Municipalities & Latitude & Longitude & Altitude & Period \\
\hline Barra S. Miguel & -7.45 & -36.19 & 520 & 1962-2019 \\
\hline Cabaceiras & -7.29 & -36.17 & 338 & 1926-2019 \\
\hline Camalaú & -7.53 & -36.49 & 565 & 1962-2019 \\
\hline Caraúbas & -7.43 & -36.29 & 460 & 1931-2019 \\
\hline Congo & -7.47 & -36.39 & 500 & 1962-2019 \\
\hline Coxixola & -7.37 & -36.36 & 465 & 1962-2019 \\
\hline Monteiro & -7.53 & -37.07 & 590 & 1911-2019 \\
\hline Prata & -7.41 & -37.04 & 600 & 1962-2019 \\
\hline São João do Tigre & -8.04 & -36.5 & 616 & 1934-2019 \\
\hline São José Cordeiros & -7.23 & -36.48 & 600 & 1963-2019 \\
\hline São Sebastião Umbuzeiro & -8.09 & -37 & 600 & 1962-2019 \\
\hline Serra Branca & -7.28 & -36.39 & 450 & 1962-2019 \\
\hline
\end{tabular}

Source: Adapted according to Medeiros (2020).

Electronic spreadsheets were used to create graphs with the annual variability of rainfall, rainfall anomalies, historical precipitation and percentage deviation. Fault filling, homogenization and consistency for rain data were carried out, in order to provide consistent information.

Frequency analysis of the distributions of the annual totals of rains was carried out by drawing up the graphs. The scale proposed by Meis et al. (1981), made available by Xavier et al. (2005), defined as follows: the annual values that came closest to the average value were characterized as intermediate, and the annual precipitation values that deviated from the average were considered as representative for the driest and most humid years. A scale of variation of $25 \%$ was used in relation to the average for the intermediate months; values above the scale were characterized as very rainy years, and those below $25 \%$, dry years in accordance with Xavier et al. (2005).

Table 2. Classification criteria used to classify municipalities as classes of monthly and annual percentage deviation to the area of the Upper Basin Paraíba.

\begin{tabular}{|c|c|}
\hline \multicolumn{2}{|c|}{ Classification Criteria } \\
\hline Percentage Deviation & Classification \\
\hline \pm 0.0 to $25.0 \%$ & Normal \\
\hline \pm 25.1 to $45.0 \%$ & Dry/Rainy \\
\hline \pm 45.1 to $70.0 \%$ & Very dry/Very rainy \\
\hline $\pm 70.1>100.0 \%$ & Extremely Dry/Extremely Rainy \\
\hline
\end{tabular}

Source: Adapted according to CPTEC/INPE/meteorological nuclei (2010). 


\section{Results and Discussion}

The Diagnosis of the variability of the pluviometric indexes in the studied area indicates a slight tendency of decrease of these annual totals over the 52 years, with a decrease of $0.2 \mathrm{~mm}$.year-1, totaling $75 \mathrm{~mm}$ in the whole series. However, it is not possible to affirm that it is a question of some climatic change, because, as already mentioned, the rainfall variability may alter this trend in the years to come. Similar results were observed by Holanda et al. (2016) showing the decadal rainfall fluctuations for Recife-PE, where in the rainy season there are positive trends and negative trends were recorded in the dry period.

As the sample series is a period of data with great significance, having a period of 52 years, it is necessary to expand the data series during the second decade of the 21 st century, for a more accurate future evaluation. As a result, it is suggested that these analyzes continue in subsequent years. Medeiros et al. (2013) obtained similar results for the area of the Rio Uruçuí Preto watershed - PI.

The oscillations of the rain are established in main characteristics of the pluviometric regime in the area of the hydrographic basin of the upper course of the Parnaíba river, being an area where two climatic types are distinguished "As" and "Bsh". The climatic types were determined by the method of Köppen (1928) and reviewed in the studies by Alvares et al. (2014), having an irregular rainfall, with its magnitude changing between municipalities. Figure 2 shows the distribution of annual precipitation between the years 1962 to 2014, where the historical annual average was $495.3 \mathrm{~mm}$. Precipitation rates range from 664.3 to $336.4 \mathrm{~mm}$, occurring among the twelve municipalities studied. The places with the highest rainfall were Camalaú, Monteiro, Prata São José dos Tigre and São Sebastião do Umbuzeiro.

Figure 2. Temporal distribution of annual precipitation and historical average in the area of the hydrographic basin of the upper course of the Paraíba River.

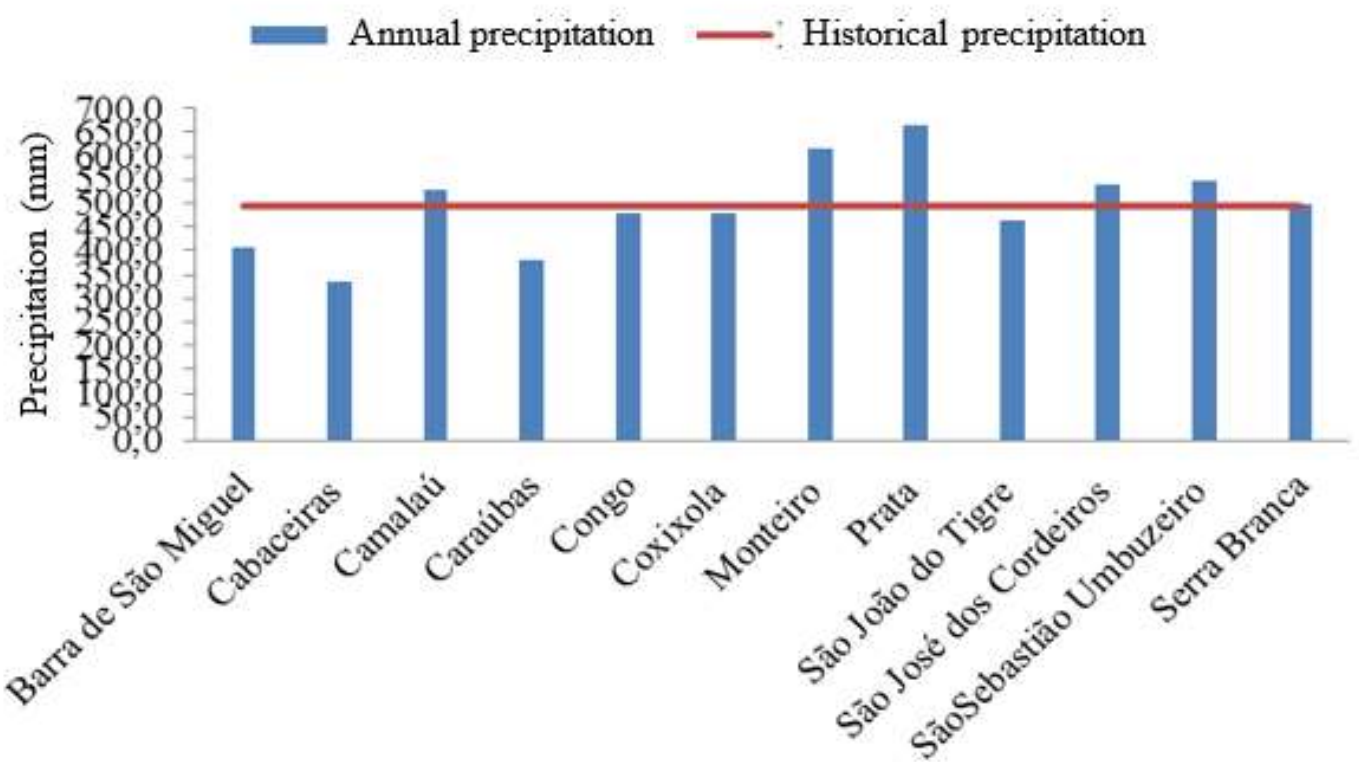

Source: Medeiros (2020).

The significant rainfall variability that occurs in the study area results in observable annual deviations. As shown in Figure 3, during the 57 years, the ones that presented the highest annual indexes were those places: Camalaú, Monteiro, Prata, São José dos Cordeiros, São Sebastião do Umbuzeiro and Serra Branca, resulting in a positive variation in relation to normal, higher than 35\%. The droughts recorded throughout the series were: Barra de São Miguel, Cabaceiras, Caraúbas, Congo, Coxixola and São José do Tigre. The El Niño phenomenon influences the considerable reduction in rainfall, since in El Niño 
years, there is a reduction in rainfall totals in the Northeast region and especially in the study region, causing severe droughts in some municipalities.

Figure 3. Annual percentage deviation of precipitation in relation to the historical average for the area of the hydrographic basin of the upper course of the Paraíba River.

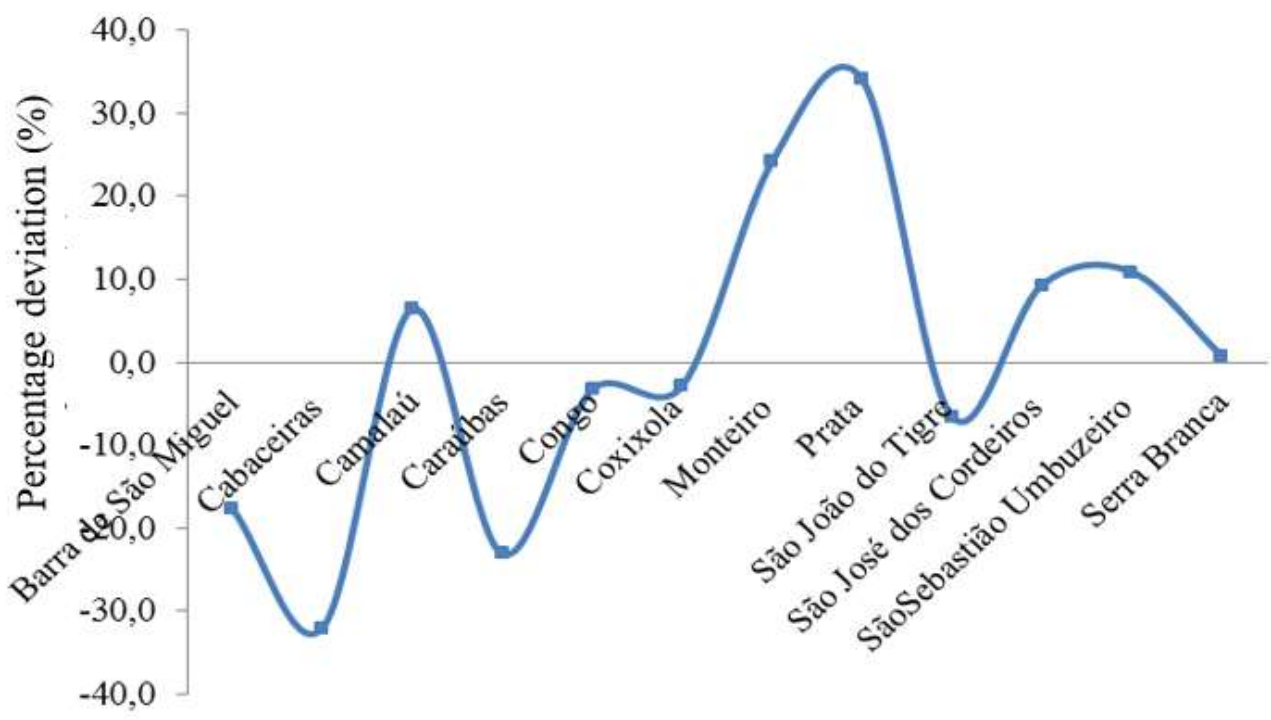

Source: Medeiros (2020).

Table 2 presents the classification criteria used to classify the municipalities according to classes of the monthly and annual percentage deviation for the upper Paraíba watershed area. Table 3 shows the names of the municipalities, annual precipitation values, historical averages, percentage deviation, precipitation anomaly and their respective classifications for the period from 1962 to 2019. The variability was also expressed in the characterization of the normal, dry year , rainy, very dry, very rainy, extremely dry and extremely rainy according to the deviation from the average, as shown in Table 3 . In the total of the 12 municipalities observed, 10 sites were classified as normal rains, one like dry and rainy. The analysis of the distribution of rainfall in the study area showed a slight tendency to reduce these annual totals over the 57 years studied, according to Table 3. 
Table 3. Municipalities, annual precipitation; historical precipitation; percentage deviation, precipitation anomaly and annual classification of the period (1962 - 2019), according to the method proposed by Meis et al. (1981) and CPTEC / INPE / meteorology nuclei (2010). For the hydrographic basin area of the upper Paraíba river course.

\begin{tabular}{|c|c|c|c|c|c|}
\hline Municipalities & $\begin{array}{c}\text { Annual } \\
\text { Precipitation } \\
(\mathrm{mm})\end{array}$ & $\begin{array}{c}\text { Historical } \\
\text { Precipitation } \\
(\mathrm{mm})\end{array}$ & $\begin{array}{c}\text { Percent } \\
\text { Deviation } \\
(\mathrm{mm}) \\
\end{array}$ & $\begin{array}{c}\text { Anomaly } \\
\text { Precipitation } \\
(\mathrm{mm})\end{array}$ & Classification \\
\hline Barra São Miguel & 407.6 & 495.3 & -17.7 & -87.6 & Normal \\
\hline Cabaceiras & 336.4 & 495.3 & -32.1 & -158.9 & Dry \\
\hline Camalaú & 527.1 & 495.3 & 6.4 & 31.8 & Normal \\
\hline Caraúbas & 380.7 & 495.3 & -23.1 & -114.6 & Normal \\
\hline Congo & 478.8 & 495.3 & -3.3 & -16.4 & Normal \\
\hline Coxixola & 481.0 & 495.3 & -2.9 & -14.3 & Normal \\
\hline Monteiro & 615.0 & 495.3 & 24.2 & 119.7 & Normal \\
\hline Prata & 664.3 & 495.3 & 34.1 & 169.1 & Rainy \\
\hline São JoséTigre & 462.7 & 495.3 & -6.6 & -32.6 & Normal \\
\hline São J. Cordeiros & 541.3 & 495.3 & 9.3 & 46.0 & Normal \\
\hline S. S. Umbuzeiro & 549.2 & 495.3 & 10.9 & 53.9 & Normal \\
\hline Serra Branca & 499.2 & 495.3 & 0.8 & 3.9 & Normal \\
\hline
\end{tabular}

Source: Medeiros (2020).

In relation to the anomalies, there was a predominance of negative anomalies in relation to the normal one. Negative anomalies in the period were found in six municipalities, and positive anomalies in five municipalities and the presence of a neutral municipality. As for the analysis carried out, these allow the identification of rainy, dry and neutral municipalities, also presenting the most variable locations and, therefore, difficult to forecast as well as the probability of recurrence over time (Figure 4). 
Figure 4. Distribution of annual precipitation, historical average and rainfall anomaly for the area of the hydrographic basin of the upper course of the Paraíba River.

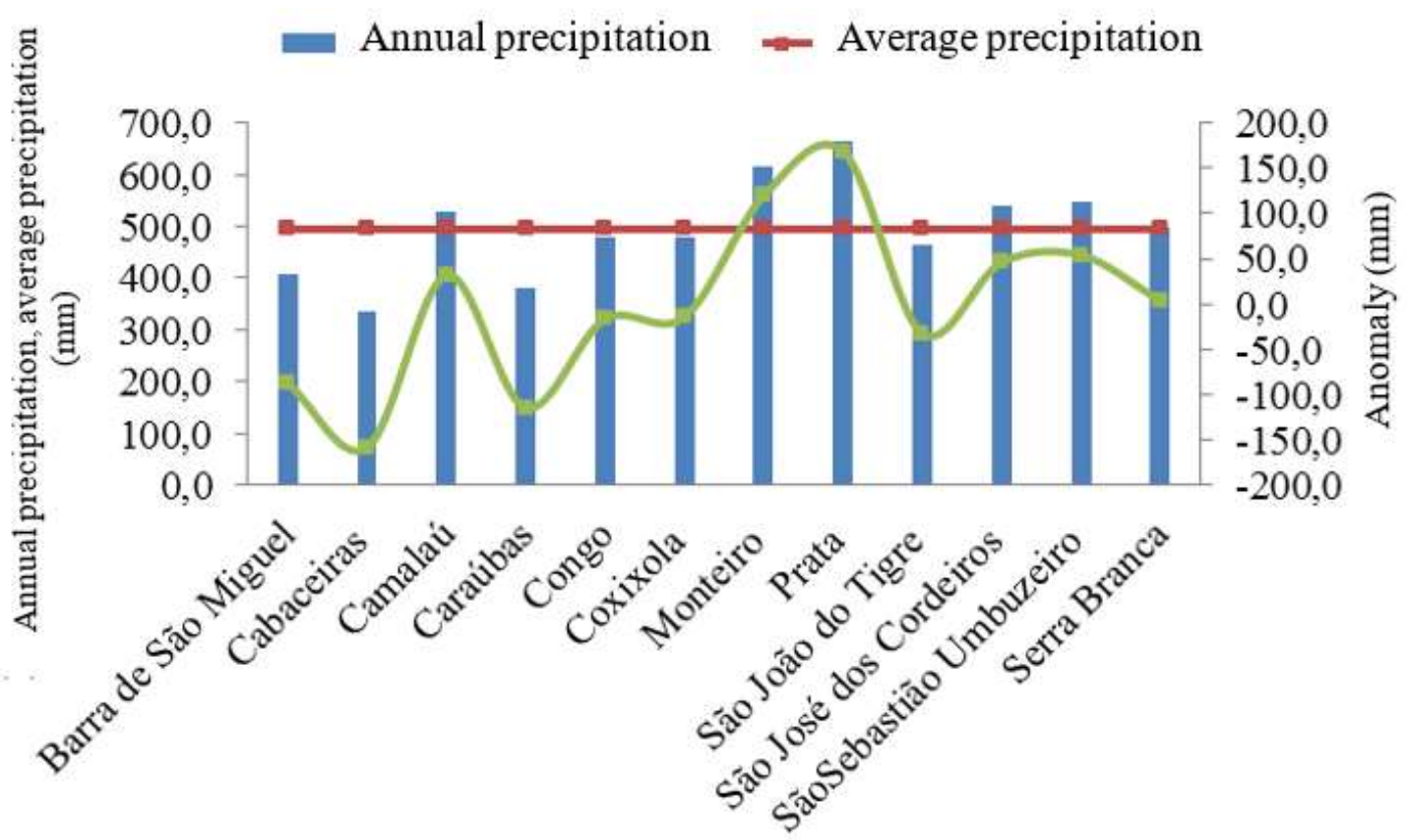

Source: Medeiros (2020).

\section{Final Considerations}

The desired results make visible the tendency of decreases in the pluviometric indexes, with oscillations of the precipitations along the sample series, which comprised the years 1962 to 2019; there was a recurrence of maximum annual precipitation values within a range of 17,13 and 9 years.

A study with a series of older years is suggested to verify the fluctuations and contributions of the El Niño and La Niña phenomena in the studied area.

\section{References}

Agência Executiva de Gestão das Águas do Estado da Paraíba. (2011). Dados Pluviais. AESA. www.aesa.pb.gov.br/index.php

Alvares, C. A., Stape, J. L., Sentelhas, P. C., Gonçalves, J. L. M., \& Sparovek, G. (2014). Köppen's climate classification map for Brazil. Meteorologische Zeitschrift, 22, 711-728. https://doi.org/10.1127/0941-2948/2013/0507

Araújo, R. R. O conforto térmico e as implicações na saúde: Uma abordagem preliminar sobre os seus efeitos na população urbana de São Luís-Maranhão. (2012). Cad. Pesq., 19(3). http://www.periodicoseletronicos.ufma.br/index.php/cadernosdepesquisa/article/view/1148

Eerola, T. T. (2003). Mudanças climáticas globais: Passado, presente e futuro. Florianópolis. https://cetesb.sp.gov.br/proclima/2014/05/12/mudancasclimaticas-globais-passado-presente-e-futuro/

Haylock, M., Peterson, T., Alves, L., Ambrizzi, T., Anunciação, M., Baez, J., Barros, V., Berlato, M., Bidegain, M., Coronel, G., Corradi, V., Garcia, V., Grimm, A., Karoly, D., Marengo J. A., Marino, M., Moncunill, D., Nechet, D., Quintana, J., Rebello, E., Rusticucci, M., Santos, J., Trebejo, I., \& Vincent, L. (2006). Trends in total and extreme South American rainfall in 1960-2000 and links with sea surface temperature. Journal of Climate, 19(8), 1490-1512. https://doi.org/10.1175/JCLI3695.1

Ichikawa, A. (2004). Global Warming - The Challenges: A Report of Japan's Global Warming Initiative. Springer.

Intergovernmental Panel on Climate Change. Impacts, Adaptation and Vulnerability. (2007). Contribution of working group II to the third assessment report of the Intergovernmental Panel on Climate Change. IPCC. Cambridge University Press.

Köppen, W., \& Geiger, R. (1928). Klimate der Erde. Wall-Map $150 \mathrm{~cm} x 200 \mathrm{~cm}$. Verlag Justus Perthes. 
Kulkarni, M. K., Revadekar, J. V., \& Varikoden, H. (2013). About the variability in thunderstorm and rainfall activity over India and its association with El Niño and La Niña. Natural Hazards, 69 (3), 2005-2019. https://doi.org/10.1007/s11069-013-0790-z

Lima, F. B., \& Santos, G. O. (2009). Balanço hídrico-espacial da cultura para o uso e ocupação atual da bacia hidrográfica do Ribeirão Santa Rita, noroeste do Estado de São Paulo. [Unpublished master's thesis]. Fundação Educacional de Fernandópolis - SP.

Marengo, J., \& Silva Dias, P. (2006). Mudanças climáticas globais e seus impactos nos recursos hídricos. In A. da C. Rebouças, B. Braga, \& J. G. Tundisi (Eds.). Águas doces do Brasil: capital ecológico, uso e conservação. (3rd ed., pp. 63-109). Editora Escrituras.

Medeiros, R. M., Sousa, F. A. S., \& Gomes Filho, M. F. (2013). Variabilidade da umidade relativa do ar e da temperatura máxima do ar e da precipitação na bacia hidrográfica do rio Uruçuí Preto - Piauí. Revista Educação Agrícola Superior, 28(1), 44-50. http://dx.doi.org/10.12722/0101-756X.v28n01a07

Medeiros, R. M., Santos, D. C., \& Gomes Filho, M. F. (2015). Análise hidroclimática da região de São João do Cariri-PB. Revista Educação Agrícola Superior, 30(2), 59-65. http://dx.doi.org/10.12722/0101-756X.v30n02a01

Medeiros, R. M. (2015). Estudo agrometeorológico para o estado da Paraíba. p. 120.

Meis, M. R. M., Coelho Netto, A. L., \& Oliveira, P. T. T. M. (1981). Ritmo e variabilidade das precipitações no vale do rio Paraíba do Sul: O caso de Resende. Revista de Hidrologia e Recursos Hídricos, 3(1), 43-51.

Sant'anna Neto, J. L. (2008). Da climatologia geográfica à geografia do clima: Gênese, paradigmas e aplicação do clima como fenômeno geográfico. Anpege, 4(4), 51-72. https://doi.org/10.5418/RA2008.0404.0004

Santana, M. O., Sediyama, G. C., Ribeiro, A., \& Silva, D. D. (2017). Caracterização da estação chuvosa para o estado de Minas Gerais. Revista Brasileira de Agrometeorologia, 15(1), 114-120.

Santos, C. A. C., \& Brito, J. I. B. (2007). Análise dos índices de extremos para o semiárido do Brasil e suas relações com TSM e IVDN. Revista Brasileira de Meteorologia, 22(3), 303-312. https://doi.org/10.1590/S0102-77862007000300003

Silva, R. M., \& Santos, C. A. G. (2016). Estimativa da precipitação do satélite TRMM para a bacia do Alto Rio Paraíba (PB). In Simpósio de Recursos Hídricos do Nordeste, 13. Anais..., 1-9.

Silva, V. P. R. (2004). On climate variability in Northeast of Brazil. Journal of Arid Environments, 58(4), 575-596. https://doi.org/10.1016/j.jaridenv.2003.12.002

Soriano, B. M. A. (1997). Caracterização climática de Corumbá-MS: Boletim de Pesquisa, 11. EMBRAPA-CPAP.

Sleiman, J., \& Silva, M. E. S. (2008). A Climatologia de precipitação e a ocorrência de veranicos na porção noroeste do Estado do Rio Grande do Sul. In Simpósio de Pós-Graduação em Geografia do Estado de São Paulo, 1. Anais...

Tammets, T., \& Jaagus, J. (2013). Climatology of precipitation extremes in Estonia using the method of moving precipitation totals. Theoretical and Applied Climatology, 111(3-4), 623-639. http://dx.doi.org/10.1007/s00704-012-0691-1

Sturm, M., Perovich, K., \& Serreza, M. C. (2005). O acelerado derretimento do Norte. Scientific American Brasil, $12,34-41$.

Superintendência do Desenvolvimento do Nordeste. (1990). Dados pluviométricos mensais do Nordeste - Paraíba: Série Pluviometria, 5. SUDENE. p. 239.

Tucci, C. E. M. (2002). Impactos da variabilidade climática e dos usos do solo nos recursos hídricos: Relatório Técnico, p.150. ANA.

Vieira, J. P. G., Souza, M. J. H., Teixeira, J. M., \& Carvalho, F. P. (2010). Estudo da precipitação mensal durante a estação chuvosa em Diamantina, Minas Gerais. Revista Brasileira de Engenharia Agrícola e Ambiental, 14, 762-767. https://doi.org/10.1590/\$1415-43662010000700012

Xavier, R. A., \& Dornellas, P. C. (2005). Análise do comportamento das chuvas no município de Arapiraca, região Agreste de Alagoas. Revista de Geografia, 14(2), 49-64. http://dx.doi.org/10.5433/2447-1747.2005v14n2p49

Zanella, M. E. (2006). Inundações urbanas em Curitiba/PR: Impactos, riscos e vulnerabilidade socioambiental no bairro Cajuru. [Unpublished doctoral dissertation]. Universidade Federal do Paraná - PR. 